University of Wollongong

Research Online

Faculty of Engineering and Information

Faculty of Engineering and Information

Sciences - Papers: Part B

Sciences

2018

Behaviour of carbon fibre-reinforced polymer-confined hollow circular concrete columns with inner polyvinyl chloride tube

Hussamaldeen GOAIZ

University of Wollongong, hagao106@uowmail.edu.au

Tao Yu

University of Wollongong, taoy@uow.edu.au

Muhammad N. S Hadi

University of Wollongong, mhadi@uow.edu.au

Follow this and additional works at: https://ro.uow.edu.au/eispapers1

Part of the Engineering Commons, and the Science and Technology Studies Commons

Research Online is the open access institutional repository for the University of Wollongong. For further information contact the UOW Library: research-pubs@uow.edu.au 


\title{
Behaviour of carbon fibre-reinforced polymer-confined hollow circular concrete columns with inner polyvinyl chloride tube
}

\author{
Abstract \\ Existing studies have shown that the use of an inner tube can significantly enhance the effectiveness of \\ confinement in fibre-reinforced polymer-confined hollow columns. The inner tube used in the existing \\ studies, however, generally had a large stiffness and also served as longitudinal reinforcement. The use of \\ a stiff inner tube is inefficient in resisting bending for hollow columns with a relatively small void and may \\ be unnecessary for constraining the inner surface of concrete. Against this background, this article \\ presents the first experimental study on fibre-reinforced polymer-confined hollow columns with an inner \\ polyvinyl chloride tube. The experimental program included a total of 18 specimens which were tested \\ under axial compression. The test variables included the section configuration (i.e. solid specimens, \\ hollow specimens and hollow specimens with a polyvinyl chloride tube) and the thickness of fibre- \\ reinforced polymer. The test results showed that due to the beneficial effect of the polyvinyl chloride tube \\ which provided constraints/confinement from inside, fibre-reinforced polymer-confined hollow columns \\ with an inner polyvinyl chloride tube generally possessed good strength and ductility compared to their \\ counterparts without a polyvinyl chloride tube.

\section{Disciplines} \\ Engineering | Science and Technology Studies

\section{Publication Details} \\ Goaiz, H. A., Yu, T. \& Hadi, M. N. S. (2018). Behaviour of carbon fibre-reinforced polymer-confined hollow \\ circular concrete columns with inner polyvinyl chloride tube. Advances in Structural Engineering: an \\ international journal, 21 (8), 1120-1133.
}




\section{Behaviour of CFRP-Confined Hollow Circular Concrete Columns}

\section{with Inner PVC Tube}

3
Hussam A. Goaiz ${ }^{1}$

${ }^{1}$ Ph.D. Candidate, School of CME Engineering, University of Wollongong, Australia. Email: hagao106@uowmail.edu.au

\section{Tao $\mathrm{Yu}^{2}$}

${ }^{2}$ Senior Lecturer, School of CME Engineering, University of Wollongong, Australia. Email: taoy@uow.edu.au

\author{
Muhammad N.S. Hadi ${ }^{3, *}$ \\ ${ }^{3}$ Associate Professor, School of CME Engineering, University of Wollongong, \\ Australia. \\ Email: $\underline{\text { mhadi@uow.edu.au }}$, 'Corresponding author
}

\section{Abstract}

Existing studies have shown that the use of an inner tube can significantly enhance the effectiveness of confinement in fibre-reinforced polymer (FRP)-confined hollow columns. The inner tube used in the existing studies, however, generally had a large stiffness and also served as longitudinal reinforcement. The use of a stiff inner tube is inefficient in resisting bending for hollow columns with a relatively small void, and may be unnecessary for constraining the inner surface of concrete. Against this background, this paper presents the first experimental study on FRP-confined hollow columns with an inner PVC tube. The experimental program included a total of 18 specimens which were tested under axial compression. The test variables included the section configuration (i.e. solid specimens, hollow specimens and hollow specimens with a PVC tube) and the thickness of FRP. The test results showed that due to the beneficial 
effect of the PVC tube which provided constraints/confinement from inside, FRPconfined hollow columns with an inner PVC tube generally possessed good strength and ductility compared to their counterparts without a PVC tube.

Keywords: CFRP; confinement; concrete; hollow columns; PVC tube.

\section{Introduction}

Fibre-Reinforced Polymer (FRP) composites have emerged rapidly as durable structural materials in recent years (Teng et al. 2002). One of the most important applications of FRP is as a confining material for concrete (e.g. Fam and Rizkalla (2001); Lam and Teng (2003); Li and Hadi (2003); Hadi (2006); Yu et al. (2013)). Because of the FRP confinement, both the strength and ductility of concrete can be significantly enhanced (Lam and Teng 2003).

Extensive studies have been conducted on FRP-confined solid circular concrete columns (e.g. Lam and Teng 2003), and the test results of such confined concrete can now be closely predicted by some of the existing stress-strain models (e.g. Lam and Teng 2003; Teng et al. 2007). By contrast, the behaviour of FRP-confined concrete in hollow circular columns is not yet well understood. In hollow circular columns, the annular concrete section is subjected to non-uniform confining pressure over its radius, and its behaviour can be much different from FRP-confined concrete in a solid circular column where the confinement is generally uniform over the cross-section.

A number of studies (Modarelli et al. 2005; Lignola et al. 2008; Yazici and Hadi 2009; Kusumawardaningsih and Hadi 2010; Yazici and Hadi 2012) have been conducted on FRP-confined hollow concrete columns. These studies suggested that the effectiveness 
of FRP confinement is much reduced because of the existence of an inner void. In a hollow column, due to the lack of constraints from inside, the concrete near the inner edge suffers from early loss of load resistance as a result of local spalling failure (Wong et al. 2008). In addition, the absence of inner pressure to the annular concrete section leads to unequal lateral confining stresses in the radial and hoop directions, further reducing the effectiveness of confinement (Yu et al. 2010a).

To minimize the detrimental effects of the inner void, existing studies have explored the use of an additional inner tube, leading to the so-called double-skin tubular columns (DSTCs) (e.g. Fam and Rizkalla 2001; Teng et al. 2007; Yu et al. 2010b). Among these studies, Fam and Rizkalla (2001) reported tests on FRP-concrete DSTCs with an inner tube made of FRP; Teng et al. (2007) and Yu et al. (2010b), among others, reported tests on FRP-concrete-steel DSTCs with an inner tube made of steel. These studies generally demonstrated that with the additional inner tube, both the performance of the column and the effectiveness of confinement can be significantly improved.

In the existing studies on FRP-confined DSTCs, the inner tubes used were typically stiff and also served as longitudinal reinforcement. However, for hollow columns with a small- or medium-size void, the use of a stiff inner tube is inefficient in resisting bending. In such cases, the main longitudinal reinforcement should be placed away from the inner edge of the concrete section, while the function of the inner tube should be mainly to restrain the inner surface of concrete for effective confinement. As a result, the inner tube could be made of a less stiff material (e.g. PVC) and be more costeffective than existing solutions. The permanent inner PVC tube has also many other advantages in construction industry besides the low cost such as; excellent durability, ease of fabrication and handling. Against this background, this paper presents an 
experimental study on FRP-confined DSTCs with a PVC inner tube (i.e. FRP-PVC DSTCs) (Figure 1a). It is worth noting that FRP-PVC DSTCs can also be a preferred solution in applications where steel should be avoided (e.g. mining applications involving cutting), considering the much lower material cost of PVC compared with FRP. In the present study, the experimental program also included tests on FRPconfined hollow columns (FCHCs) (Figure 1b) and FRP-confined solid cylinder (FCSCs) (Figure 1c) for comparison.

\section{Experimental program}

\subsection{Specimens details}

In total, 18 specimens were prepared and tested under concentric axial compression. All the specimens had an outer diameter of $150 \mathrm{~mm}$ and a height of $300 \mathrm{~mm}$. These specimens were divided into three groups according to the section configuration. Specimens in the first group had an inner PVC tube (Figure 1a), specimens in the second group were hollow cylinders with an inner void of $90 \mathrm{~mm}$ (Figure 1b), while specimens in the third group were solid cylinders (Figure 1c). The PVC tube had an outer diameter of $90 \mathrm{~mm}$ and a thickness of $1.5 \mathrm{~mm}$. Each group consisted of two control specimens without FRP and two pairs of FRP-confined specimens wrapped with one and two layers of carbon FRP (CFRP) sheet, respectively. The details of all the specimens are summarized in Table 1.

Each specimen is identified with an acronym (Table 1), which starts with a letter "HC" to represent hollow core specimens or "S" to represent solid specimens. For FRPconfined specimens, this is then followed by " $1 \mathrm{~F}$ " or " $2 \mathrm{~F}$ " to represent one or two layers of CFRP sheet. The letter "T" for some specimens is used to indicate that the specimens had an inner PVC tube. The number "1" or " 2 " at the end is used to differentiate two 
nominally identical specimens. For example, specimen "HC1FT-1" was the first of two nominally identical hollow core specimens with an inner PVC tube and a one-layer CFRP wrap.

\subsection{Material properties}

Three concrete cylinders $(100 \mathrm{~mm} \times 200 \mathrm{~mm})$ were tested during the test period following AS 1012.9 (1999) and the average compressive strength was found to be 52.5 MPa.

Three coupons were cut from the PVC tube and tested under tension according to ASTM D638 (2014). The typical tensile stress-strain curve obtained from these tests is shown in Figure 2, where the tensile strains were obtained from a clip-on extensometer attached to the specimen. The ultimate tensile stress, the ultimate tensile strain and the elastic modulus were found to be $44.47 \mathrm{MPa}, 54 \%$ and $3.6 \mathrm{GPa}$, respectively. In addition, two PVC tubes with a length of $300 \mathrm{~mm}$ were tested under axial compression and the test results are shown in Figure 3.

Tensile tests on CFRP coupons were conducted according to ASTM D7565 (2010) standard. The test results showed that the average tensile force per unit width of onelayer CFRP (0.35 mm thickness) and two-layer CFRP (0.7 mm thickness) were 593.7 $\mathrm{N} / \mathrm{mm}$ and $1262.5 \mathrm{~N} / \mathrm{mm}$, respectively.

\subsection{Test set-up and instrumentation}

All compression tests were carried out using a Denison universal testing machine with a loading capacity of $5000 \mathrm{kN}$ (see Figure 4). One LVDT was used to measure the axial 
131 strain of the mid-height region of $115 \mathrm{~mm}$. In addition, two strain gauges with a gauge

132 length of $5 \mathrm{~mm}$ were attached at the mid-height of the CFRP wrap to measure the hoop 133 strains. All specimens were axially loaded up to failure with a displacement rate of 0.5 $134 \mathrm{~mm} /$ minute.

\section{Experimental results and discussions}

\section{$137 \quad 3.1 \quad$ Failure modes}

All unconfined specimens failed by the crushing and spalling of concrete at the midheight of the specimens. For hollow specimens without a PVC tube, damage on the inner surface was found after test. All CFRP-confined specimens failed by the rupture of CFRP due to hoop tension, except for Specimens S1F-2, HC1F-2 and HC1FT-2. For these three specimens, premature failure occurred near one end; the results of these specimens were thus excluded from the discussions below. This premature failure had been caused by the non-uniform distribution of the load on the capped surface of the specimen due to lack of squareness of the capping surface.

\subsection{Axial stress-strain behaviour}

The key test results are summarized in Table 2. The axial stress-strain curves of concrete in solid specimens are compared with those of concrete in hollow specimens without a PVC tube in Figure 5. For clarity of presentation, the stress-strain curves of confined specimens are all terminated at a point corresponding to the rupture of CFRP. 
153 Figure 5a shows that the unconfined strength of hollow specimens was slightly lower 154 than that of solid specimens (see also Table 2). In addition, the hollow specimens 155 generally had a steeper descending branch than the solid specimens, suggesting that the 156 inner void had a negative effect on both the strength and ductility of the specimen.

157 Figures $5 \mathrm{~b}$ and $5 \mathrm{c}$ show that the behaviour of CFRP-confined hollow specimens is quite 158 different from that of the corresponding solid specimens. The latter generally had a 159 bilinear stress-strain curve while the curves of the former typically had a descending branch. As a result, the CFRP-confined hollow specimens generally had a much lower peak stress than the corresponding solid specimens, although the ultimate axial strains of the former were comparable to or even larger than the latter. For hollow specimens, the stress decreased more rapidly after the peak value for specimens with a weaker CFRP wrap (see Figures $5 \mathrm{~b}$ and $5 \mathrm{c}$ ).

Figure 6 shows a comparison between the stress-strain curves of concrete in hollow specimens and those of concrete in the corresponding specimens with a PVC tube. When calculating the axial stress of concrete in the latter, the load contribution of the PVC tube was ignored as it was generally rather small (peak load $=22 \mathrm{kN}$ ) compared with that of the concrete (peak load of unconfined concrete $=522 \mathrm{kN}$ ).

172 Figure 6a shows that the presence of an inner PVC tube had a marginal effect on the 173 behaviour of the unconfined concrete. Figure $6 \mathrm{~b}$, however, shows that the additional 174 PVC tube reduced the decrease in stress in the descending second branch of the stressstrain curves of one-layer CFRP-confined specimens. For the specimen without a PVC tube (i.e. HC1F-1), the stress decrease in the second branch was $33 \%$ of the peak stress, 
177 while for the specimen with a PVC tube (i.e. HC1FT-1) the stress decrease was only 9\%

178 of the peak stress. For two-layer CFRP-confined specimens, Figure $6 \mathrm{c}$ shows that the 179 effect of PVC tube was even more obvious: Specimens HC2FT-1, 2 had a bilinear 180 stress-strain curve with two ascending branches. By contrast, the curves of the two 181 specimens without a PVC tube both had a clear descending second branch which was 182 lower than that of their counterparts with a PVC tube. This is believed to be due to two important functions of the inner PVC tube: (1) preventing local spalling failure of concrete near the inner edge; and (2) providing inner pressure to the annular concrete section.

While Figures $6 \mathrm{~b}$ and $6 \mathrm{c}$ clearly show the beneficial effect of the inner PVC tube, it may be noted that such effect does not seem to be significant. This was due to the use of a thin PVC tube in the present study whose stiffness was rather small. The PVC tube had a thickness of $1.5 \mathrm{~mm}$ and an elastic modulus of $3.6 \mathrm{GPa}$, so in terms of axial stiffness it was only equivalent to a steel tube of the same diameter and a thickness of around 0.03 $\mathrm{mm}$. When a thicker PVC tube is used, it can be expected that the beneficial effect of the inner tube would be more pronounced.

\subsubsection{Comparison between inner tube of PVC and steel}

To compare the behaviour of PVC tube and steel tube, the results of four FRP-confined

197 DSTC specimens with inner steel tube $(2.1 \mathrm{~mm}$ thickness $)$ were selected from a previous study that was conducted by Wong et al. (2008). The four FRP-confined DSTC specimens (D37-C1-I, D37-C1-II, D37-C2-I and D37-C1-II) were selected for 
$(152.5 \mathrm{~mm}$ diameter $\times 305 \mathrm{~mm}$ height $\times 88 \mathrm{~mm}$ inner void $)$ to the specimens with inner

202

203

204

205

206

207

208

209

210

211

212

213

214

215

216

217

218

219

220

221

222

223

224

225

PVC tubes presented in this study. In addition, these specimens had nearly the same strength of the FRP confinement (average tensile strength of $1825.5 \mathrm{MPa}$ ).

Table 3 shows the results of the axial stress and axial strain of the four DSTC specimens and Specimens HC1FT-1, HC2FT-1 and HC2FT-2, in which $\sigma_{\max }$ is the maximum axial stress, and $\varepsilon_{\mathrm{u}}$ is the ultimate strain at the rupture of FRP confinement. The results presented in Table 3 showed that the axial stress increase $\left(\sigma_{\max } / f_{c}^{\prime}\right)$ of Specimens D37C1-I, II was $10.7 \%$ higher than Specimen HC1FT-1. Also, the stress increase of Specimens D37-C2-I, II was 19.4\% higher than Specimens HC2FT-1, 2. Whereas, the strain increase $\left(\varepsilon_{\mathrm{u}} / \varepsilon_{\mathrm{co}}\right)$ of Specimens HC1FT-1 and HC2FT-1, 2 were $71.9 \%$ and $17.3 \%$ higher than Specimens D37-C1-I, II and D37-C2-I, II, respectively. Thus, using an internal steel tube in FRP-confined DSTC specimen has the advantage of increasing the axial stress capacity. The using of an internal PVC tube however, has the advantage of increasing the axial strain. In addition, the PVC tube has the advantages of low cost, low self-weight and ease of fabrication over the steel tube.

\subsection{Axial-hoop strain behaviour}

Figures 7 and 8 show the axial-hoop strain curves of one-layer and two-layer CFRPconfined specimens, respectively. In the two figures, the axial strains were obtained from readings of the LVDT while the hoop strains were averaged from two strain gauges attached at the mid-height of the CFRP wrap.

It is evident from both figures that the lateral expansion behaviour of hollow specimens was quite different from that of the corresponding solid specimens. Such difference became significant after an axial strain of around 0.0025 , when the lateral expansion of 
concrete started to increase rapidly. In hollow specimens, the concrete could move

227

228

229

230

231

232

233

234

235

236 towards the inner void because of the absence of constraints from inside, leading to a reduced outward expansion as measured by the hoop strain gauges on the outer CFRP wrap (Figures 7 and 8). It is easy to understand that the curves of the specimens with a PVC tube generally lie between those of the corresponding solid and hollow specimens, due to the inner constraint/confinement provided by the PVC tube. It should also be noted that the effect of PVC tube on the outward expansion of concrete appeared to be more obvious for two-layer specimens (Figure 8) than one-layer specimens. This was probably due to the stronger confinement provided by the two-layer CFRP, which led to more significant inward movement of the inner surface and in turn activated the PVC tube more effectively. Figure 9 shows the shape of two PVC tubes after test in Specimens HC1FT-1 and HC2FT-1, respectively. It is evident that the deformation of the latter was much more significant than the former. The inward buckling that was observed in the mid-height region of the PVC tube of Specimen HC2FT-1 (Figure 9b) can be attributed to the local stress concentration on the FRP confinement of this specimen.

\subsection{Effect of CFRP confinement}

The effect of CFRP confinement is illustrated in Figure 10. Figure 10a shows the effect of CFRP confinement for hollow specimens with a PVC tube. The shape of the curves was found to be significantly affected by the FRP confinement: the curves of the two unconfined specimens (i.e. HCT-1, 2) both had a descend branch, the one-layer specimen (i.e. HC1FT-1) had an approximately elastic-perfectly plastic curve, while the two-layer specimens (i.e. H2FT-1, 2) had a hardened bilinear curve. Besides, the superior performance of two-layer specimens was believed to be also partially due to 
251 the more effective confinement provided by the PVC tube from inside as discussed

252 above.

253 Figure 10b shows the effect of CFRP confinement for hollow specimens, where all the curves had a descending branch. Again, the behaviour of the specimens depended on the amount of confining CFRP, and the two-layer specimens (i.e. HC2F-1, 2) are shown to have the largest strength. It may be noted that the stress decrease in the descending branch became less when a stronger CFRP wrap was used.

As expected, for solid specimens, both the strength and the ductility of concrete was much enhanced because of the confinement of CFRP, and such enhancement was more pronounced for specimens with a two-layer CFRP than those with a one-layer CFRP (Figure 10c).

\subsection{Ductility of specimens}

The ductility of concrete columns is considered as one of the structural design aspects that need to be taken into account, particularly when concrete columns are resisting a high axial load. Ductility can be improved by using CFRP sheets to confine concrete columns. In this study, the calculation of the ductility depends on the axial stress-strain behaviour of the confined concrete which is the main component taking axial loads. The calculation method used is according to GangaRao et al. (2007) which is suitable for concrete with softened and hardened axial stress-strain behaviour, as shown in Eqn 1 below: 
where $\mu_{\varepsilon}$ is the specimen's ductility, $\varepsilon_{u}$ is the specimen's strain at $85 \%$ of the maximum stress at post-yielding (for unconfined specimens) or is equal to the specimen's strain at rupture of FRP confinement (for FRP-confined specimens) and $\varepsilon_{y}$ is the strain at yield stress.

The method of defining the yield point is based on the equivalent elasto-plastic method that was suggested by Park (1989). In this study, three different types of stress-strain curves were observed. Figure 11 shows how yield stresses and yield strains are determined.

The results of ductility in this study are summarized in Table 4. In general, test results indicate that the ductility of concrete specimens can be significantly improved by applying CFRP confinement. Applying two-layer of CFRP-confinement shows an outstanding improvement in term of the specimens' ductility. The highest average value of ductility 15.5 was achieved by Specimens HC2FT (Hollow specimen with an inner PVC tube and two layers of CFRP confinement), while the lowest average value of ductility 2.25 was obtained by Specimens HC (unconfined hollow specimen). Table 4 presents the ductility values of the specimens and shows the comparative results of the ductility of CFRP confined specimens and unconfined ones. According to the results presented in Table 4, the ductility of hollow specimens can be enhanced to be of close values to those of the FRP-confined solid specimens by using PVC tube for internal confinement. Figure 12 presents a comparison between the normalized average maximum stress and the normalized average ductility for all specimens. 


\section{Conclusions}

298 This paper has presented and interpreted the results of a series of compression tests on

299 CFRP-confined hollow concrete specimens with and without an inner PVC tube. The 300 failure mode, axial stress-strain behaviour and axial-hoop strain behaviour of the test 301 specimens have been discussed. Based on the test results and discussions presented 302 above, the following conclusions can be drawn:

303 1. The inner void in a concrete cylinder led to a slight decrease in the strength and 304 ductility of unconfined concrete.

2. CFRP-confined hollow specimens with an inner PVC tube generally possessed good ductility and were higher than their counterparts without a PVC tube. This was due to the beneficial effect of the PVC tube which provided constraints/confinement from the inside.

3. Under the same axial strain, the outward lateral expansion of CFRP-confined hollow specimens was generally lower than the corresponding solid specimens. This suggests that the ultimate axial strain of the former may be larger than the latter for the same confining material.

4. Compared with hollow specimens without an inner tube, the presence of an inner PVC tube led to an increased outward expansion of the CFRP-confined specimens, but this effect was only obvious when the CFRP confinement was strong (i.e. by using a two-layer wrap).

5. For unconfined specimens, solid specimens exhibited higher ductility than hollow specimens. For confined specimens, however, the ductility of hollow specimens with an internal PVC tube can be enhanced to show close values of ductility compared to those of the solid specimens. 
322 It should also be noted that the PVC tube used in the present study had only a small 323 stiffness. Further studies are needed to investigate the effect of thickness of PVC tube. It

324 can be expected the beneficial effects are even more pronounced than those presented in 325 this paper if a thicker PVC tube was used.

\section{Acknowledgement}

328 The authors are grateful for the financial supports received from the Australian Research Council through a Discovery Early Career Researcher Award (Project ID: DE140101349) for the second author. The authors would like to thank Messers Fernando Escribano, Cameron Neilson and Ritchie Mclean from the high bay laboratory of the School of Civil, Mining and Environmental Engineering at the University of Wollongong, Australia for their technical supports during the tests. The first author is grateful for the financial supports received from the Higher Committee for Education Development in Iraq.

\section{References}

American Society for Testing and Materials. (2010). "Standard Test Method for for Strengthening of Civil Structures", ASTM D7565/D7565M-10, West Conshohocken, PA.

342 American Society for Testing and Materials. (2014). "Standard Test Method for Tensile 343 Properties of Plastics", ASTM D638-14, West Conshohocken, PA. 
344 Australian Standard. (1999). "Methods of Testing Concrete", AS 1012 -1999, Sydney, 345 NSW.

346 Fam, A.Z., \& Rizkalla, S.H. (2001) "Behaviour of axially loaded concrete-filled circular 347 fiber-reinforced polymer tubes", ACI Structural Journal, Vol. 98, No. 3, pp. 451-461.

348 GangaRao, H.V.S., Taly, N. and Viyaj, P.V. (2007). "Reinforced concrete design with FRP composites", New York, Wiley.

Hadi, M.N.S. (2006). "Behaviour of FRP wrapped normal strength concrete columns under eccentric loading”, Composite Structures Journal, Vol. 72, No. 4, pp. 503-511.

Kusumawardaningsih, Y. and Hadi, M.N.S. (2010). "Comparative behaviour of hollow columns confined with FRP composites”, Composite Structures, Vol. 93, pp. 198-205. Lam, L., and Teng, J.G. (2003). “Design-Oriented stress-strain model for FRP-confined concrete", Construction and Building Materials, Vol. 17, pp. 471- 489.

Li, J., and Hadi, M.N.S. (2003). "Behaviour of externally confined high-strength concrete columns under eccentric loading”, Composite Structures, Vol. 62, No. 1, pp. 145-153.

Lignola, G.P., Prota, A., Manfredi, G., and Cosenza, E. (2008). "Unified theory for confinement of RC solid and hollow circular columns", Composites Part B, Vol. 39, No. 7-8, pp.1151-1160.

Modarelli, R., Micelli, F., and Manni, O. (2005). "FRP-confinement of hollow concrete cylinders and prisms", American Concrete Institute Special Publication, Vol. 230, No. 58, pp. 1029-1046.

Park, R. (1989) "Evaluation of ductility of structures and structural assemblages from laboratory testing." Bulletin New Zealand National Society for Earthquake Engineering, Vol. 22, No. 3, pp.155-66. 
Teng, J.G., Chen, J.F., Smith, S.T., and Lam, L., eds, (2002). "FRP-strengthened RC structures", John Wiley and Sons, West Sussex, U.K.

Teng, J.G., Yu, T., Wong, Y.L., and Dong, S.L. (2007). "Hybrid FRP concrete steel tubular columns: Concept and behaviour", Construction and Building Materials, Vol. 21, No. 4, pp. 846-854.

Wong, Y.L., Yu, T., Teng, J.G. and Dong, S.L. (2008). "Behaviour of FRP-confined concrete in annular section columns", Composites Part B: Engineering, No. 39, pp. $451-466$.

Yazici, V., and Hadi, M.N.S. (2009). “Axial load-bending moment diagrams of carbon FRP wrapped hollow core reinforced concrete columns", Journal of Composites for Construction, Vol. 13, No. 4, pp. 262-268.

Yazici, V., and Hadi, M.N.S. (2012). "Normalized confinement stiffness approach for modelling FRP-confined concrete", Journal of Composites for Construction, Vol. 16, No. 5, pp. 520-528.

Yu, T., Teng, J.G., Wong, Y.L., Dong, S.L. (2010a). "Finite element modelling of confined concrete-I: Drucker-Prager type plasticity model”, Engineering Structures, Vol. 32, No. 3, pp. 665-79.

Yu, T., Teng, J.G. and Wong, Y.L. (2010b). "Stress-strain behavior of concrete in hybrid double-skin tubular columns", ASCE Journal of Structural Engineering, Vol. 136, No. 4, pp. 379-389.

Yu, T. and Teng, J.G. (2013). "Behavior of hybrid FRP-concrete-steel double-skin tubular columns with a square outer tube and a circular inner tube subjected to axial compression”, ASCE Journal of Composites for Construction, Vol. 17, No. 2, pp. 271279. 
$394 \quad$ List of Tables

395 Table 1. Details of test specimens.

396 Table 2. Key test results.

397 Table 3. Comparison between inner tubes of PVC and steel

398 Table 4. Axial strain and ductility test results

399

400

401

402

403

404

405

406

407

408

409

410

411

412

413

414

415

416

417

418 


\section{$420 \quad$ List of Figures}

421 Figure 1. Details of test specimens.

422 Figure 2. Typical tensile stress-strain behaviour of PVC coupon.

423 Figure 3. Axial compressive load-deformation behaviour of PVC tube.

424 Figure 4. Instrumentation of compression test.

425 Figure 5. Axial stress-strain curves of solid and hollow specimens.

426 Figure 6. Axial stress-strain curves of hollow with and without PVC tube specimens.

427 Figure 7. Axial-hoop strain response of one layer of CFRP confinement.

428 Figure 8. Axial-hoop strain responses of two layers of CFRP confinement.

429 Figure 9. PVC tube deformations of Specimens HC1FT-1 and HC2FT-1.

430 Figure 10. Effect of CFRP confinements on stress-strain response.

431 Figure 11. Definitions for yield stress and yield strain (a) unconfined specimens; (b) confined specimens with softening behaviour; (c) confined specimens with hardening behaviour (Park, 1989).

434 Figure 12. Normalized maximum stress and normalized average ductility 
Table 1 Details of test specimens

\begin{tabular}{|c|c|c|c|c|}
\hline \multicolumn{2}{|c|}{ Specimen } & \multirow{2}{*}{$\begin{array}{c}\text { Inner Hole } \\
\text { Diameter } \\
(\mathbf{m m})\end{array}$} & \multirow{2}{*}{$\begin{array}{c}\text { Number of } \\
\text { CFRP } \\
\text { Layers }\end{array}$} & \multirow{2}{*}{$\begin{array}{c}\text { Inner PVC tube } \\
\text { thickness } \\
(\mathbf{m m})\end{array}$} \\
\hline Type & Label & & & \\
\hline \multirow{6}{*}{$\begin{array}{l}\text { Hollow core } \\
\text { with inner } \\
\text { PVC tube }\end{array}$} & HCT-1 & 87 & ---- & 1.5 \\
\hline & HCT-2 & 87 & ---- & 1.5 \\
\hline & HC1FT-1 & 87 & 1 & 1.5 \\
\hline & HC1FT-2 & 87 & 1 & 1.5 \\
\hline & HC2FT-1 & 87 & 2 & 1.5 \\
\hline & HC2FT-2 & 87 & 2 & 1.5 \\
\hline \multirow[t]{6}{*}{ Hollow core } & HC-1 & 90 & ---- & ---- \\
\hline & HC-2 & 90 & ---- & ---- \\
\hline & HC1F-1 & 90 & 1 & --- \\
\hline & HC1F-2 & 90 & 1 & ---- \\
\hline & HC2F-1 & 90 & 2 & ---- \\
\hline & HC2F-2 & 90 & 2 & ---- \\
\hline \multirow[t]{6}{*}{ Solid } & S-1 & Solid & --- & ---- \\
\hline & S-2 & Solid & ---- & ---- \\
\hline & S1F-1 & Solid & 1 & ---- \\
\hline & S1F-2 & Solid & 1 & --- \\
\hline & S2F-1 & Solid & 2 & ---- \\
\hline & S2F-2 & Solid & 2 & ---- \\
\hline
\end{tabular}

447 
Table 2 Key test results

\begin{tabular}{|c|c|c|c|c|c|c|c|c|}
\hline \multirow{2}{*}{$\begin{array}{l}\text { Specimens } \\
\text { Label }\end{array}$} & \multicolumn{2}{|c|}{$\begin{array}{c}\text { Maximum Stress } \\
\sigma_{\max } \\
(\mathrm{MPa})\end{array}$} & \multicolumn{2}{|c|}{$\begin{array}{c}\text { Strain } \\
\text { at Maximum Stress } \\
\varepsilon_{\max }\end{array}$} & \multicolumn{2}{|c|}{$\begin{array}{c}\text { Strain } \\
\text { at Rupture of FRP } \\
\varepsilon_{u}\end{array}$} & \multicolumn{2}{|c|}{$\begin{array}{c}\text { Hoop Rupture } \\
\text { Strain } \\
\varepsilon_{\mathrm{h}, \text { rup }}\end{array}$} \\
\hline & $\sigma_{\max }$ & $\begin{array}{c}\text { Average } \\
\sigma_{\max } \\
\end{array}$ & $\varepsilon_{\max }$ & $\begin{array}{c}\text { Average } \\
\varepsilon_{\max } \\
\end{array}$ & $\varepsilon_{\mathrm{cu}}$ & $\begin{array}{c}\text { Average } \\
\varepsilon_{\mathrm{cu}} \\
\end{array}$ & $\varepsilon_{\mathrm{h}, \text { rup }}$ & $\begin{array}{c}\text { Average } \\
\varepsilon_{\mathrm{h}, \text { rup }}\end{array}$ \\
\hline HCT-1 & 46.7 & \multirow{2}{*}{46.2} & 0.0028 & \multirow{2}{*}{0.0028} & --- & \multirow[t]{2}{*}{ 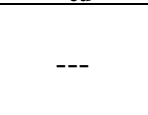 } & --- & \multirow[t]{2}{*}{, } \\
\hline HCT-2 & 45.7 & & 0.0027 & & --- & & --- & \\
\hline HC1FT-1 & 54.1 & 54.1 & 0.0053 & 0.0053 & 0.0295 & 0.0295 & 0.0086 & 0.0086 \\
\hline HC2FT-1 & 66.5 & \multirow{2}{*}{65.0} & 0.0281 & \multirow{2}{*}{0.0199} & 0.0281 & \multirow{2}{*}{0.0287} & 0.0113 & \multirow{2}{*}{0.0122} \\
\hline HC2FT-2 & 63.5 & & 0.0116 & & 0.0293 & & 0.0130 & \\
\hline HC-1 & 46.8 & \multirow[b]{2}{*}{46.9} & 0.0023 & \multirow{2}{*}{0.0024} & --- & \multirow[b]{2}{*}{--- } & --- & \multirow[b]{2}{*}{---} \\
\hline $\mathrm{HC}-2$ & 46.9 & & 0.0025 & & --- & & --- & \\
\hline HC1F-1 & 54.5 & 54.5 & 0.0048 & 0.0048 & 0.0298 & 0.0298 & 0.0091 & 0.0091 \\
\hline $\mathrm{HC} 2 \mathrm{~F}-1$ & 60.9 & \multirow{2}{*}{62.8} & 0.006 & \multirow{2}{*}{0.0065} & 0.0274 & \multirow{2}{*}{0.0268} & 0.0101 & \multirow{2}{*}{0.0104} \\
\hline $\mathrm{HC} 2 \mathrm{~F}-2$ & 64.7 & & 0.007 & & 0.0261 & & 0.0106 & \\
\hline S-1 & 49.6 & \multirow{2}{*}{48.9} & 0.0028 & \multirow{2}{*}{0.0030} & "--- & \multirow{2}{*}{--- } & $\begin{array}{l}-- \\
\end{array}$ & \multirow[b]{2}{*}{--- } \\
\hline$\overline{S-2}$ & 48.13 & & 0.0032 & & --- & & --- & \\
\hline S1F-1 & 70.3 & 70.3 & 0.0316 & 0.0316 & 0.0316 & 0.0316 & 0.0098 & 0.0098 \\
\hline S2F-1 & 104.6 & \multirow{2}{*}{101.8} & 0.0214 & \multirow{2}{*}{0.0233} & 0.0214 & \multirow{2}{*}{0.0233} & 0.0129 & \multirow{2}{*}{0.0133} \\
\hline S2F-2 & 98.9 & & 0.0251 & & 0.0251 & & 0.0137 & \\
\hline
\end{tabular}

458

459

460

461

462

463

464

465

466

467

468

469 
Table 3 Comparison between inner tubes of PVC and steel

\begin{tabular}{|c|c|c|c|c|c|c|}
\hline \multirow{2}{*}{$\begin{array}{c}\text { Specimens } \\
\text { Label }\end{array}$} & \multicolumn{2}{|c|}{$\begin{array}{c}\text { Maximum Stress } \\
\sigma_{\max } \\
(\mathrm{MPa})\end{array}$} & \multirow{2}{*}{$\begin{array}{c}\text { Stress } \\
\text { Enhancement }\end{array}$} & \multicolumn{2}{|c|}{$\begin{array}{c}\text { Strain } \\
\text { at Rupture of FRP } \\
\text { Tube } \varepsilon_{\mathrm{cu}}\end{array}$} & \multirow{2}{*}{$\begin{array}{c}\text { Strain } \\
\text { Enhancement } \\
\varepsilon_{\mathrm{cu}} / \varepsilon_{\mathrm{co}}\end{array}$} \\
\hline & $\sigma_{\max }$ & $\begin{array}{c}\text { Average } \\
\sigma_{\max }\end{array}$ & & $\varepsilon_{\mathrm{cu}}$ & $\begin{array}{c}\text { Average } \\
\varepsilon_{\mathrm{cu}}\end{array}$ & \\
\hline HC1FT-1 & 54.1 & 54.1 & 1.03 & 0.0295 & 0.0295 & 9.8 \\
\hline HC2FT-1 & 66.5 & \multirow{2}{*}{65.0} & \multirow{2}{*}{1.24} & 0.0281 & \multirow{2}{*}{0.0287} & \multirow{2}{*}{9.5} \\
\hline HC2FT-2 & 63.5 & & & 0.0293 & & \\
\hline D37-C1-I & 42.9 & \multirow{2}{*}{42.2} & \multirow{2}{*}{1.14} & 0.0166 & \multirow{2}{*}{0.0150} & \multirow{2}{*}{5.7} \\
\hline D37-C1-II & 41.4 & & & 0.0133 & & \\
\hline D37-C2-I & 55.9 & \multirow{2}{*}{54.4} & \multirow{2}{*}{1.48} & 0.0235 & \multirow{2}{*}{0.0212} & \multirow{2}{*}{8.1} \\
\hline D37-C2-II & 52.9 & & & 0.0188 & & \\
\hline
\end{tabular}

472

473

474

475

476

477

478

479

480

481

482

483

484

485

486 
Table 4 Axial strain and ductility test results

\begin{tabular}{|c|c|c|c|c|c|c|}
\hline \multirow{2}{*}{$\begin{array}{c}\text { Specimen } \\
\text { Label }\end{array}$} & \multicolumn{3}{|c|}{ Strain $\varepsilon$} & \multirow{2}{*}{$\begin{array}{c}\text { Ductility } \\
\mu_{\varepsilon}\end{array}$} & \multirow{2}{*}{$\begin{array}{l}\text { Average } \\
\text { Ductility }\end{array}$} & \multirow{2}{*}{$\begin{array}{c}\text { Normalized } \\
\text { average } \\
\text { ductility }\end{array}$} \\
\hline & $\begin{array}{c}\text { Strain at } \\
\text { Yield stress } \\
\sigma_{\mathrm{y}} \\
\end{array}$ & $\begin{array}{c}\text { Strain at } \\
\text { Rupture stress } \\
\varepsilon_{\mathrm{u}} \\
\end{array}$ & $\begin{array}{c}\text { Strain at } \\
85 \% \text { of } \\
\sigma_{\max } \\
\end{array}$ & & & \\
\hline НCТ-1 & 0.0018 & --- & 0.0046 & 2.5 & \multirow{2}{*}{2.4} & \multirow{2}{*}{1.00} \\
\hline HCT-2 & 0.0018 & $\begin{array}{ll}-- \\
-\end{array}$ & 0.0042 & 2.3 & & \\
\hline HC1FT-1 & 0.0020 & 0.0295 & ---- & 14.8 & 14.8 & 6.17 \\
\hline HC2FT-1 & 0.0018 & 0.0281 & ---- & 15.6 & \multirow{2}{*}{15.5} & \multirow{2}{*}{6.46} \\
\hline HC2FT-2 & 0.0019 & 0.0293 & ---- & 15.4 & & \\
\hline HC-1 & 0.0016 & --- & 0.0033 & 2.1 & \multirow{2}{*}{2.25} & \multirow{2}{*}{1.00} \\
\hline HC-2 & 0.0016 & --- & 0.0038 & 2.4 & & \\
\hline HC1F-1 & 0.0021 & 0.0267 & ---- & 12.7 & 12.7 & 5.64 \\
\hline $\mathrm{HC} 2 \mathrm{~F}-1$ & 0.0020 & 0.0274 & ---- & 13.7 & \multirow{2}{*}{13.4} & \multirow{2}{*}{5.96} \\
\hline $\mathrm{HC} 2 \mathrm{~F}-2$ & 0.0020 & 0.0261 & ---- & 13.1 & & \\
\hline S-1 & 0.0018 & $\begin{array}{l}--- \\
\end{array}$ & 0.0056 & 3.3 & \multirow{2}{*}{3.15} & \multirow{2}{*}{1.00} \\
\hline S-2 & 0.0017 & --- & 0.0048 & 3.0 & & \\
\hline S1F-1 & 0.0019 & 0.0243 & $\begin{array}{ll}--- \\
\end{array}$ & 12.7 & 12.7 & 4.03 \\
\hline S2F-1 & 0.0015 & 0.0214 & ---- & 14.2 & \multirow{2}{*}{15.45} & \multirow{2}{*}{4.90} \\
\hline S2F-2 & 0.0015 & 0.0251 & ---- & 16.7 & & \\
\hline
\end{tabular}

488

489

490

491

492

493

494

495

496

497

498

499

500 


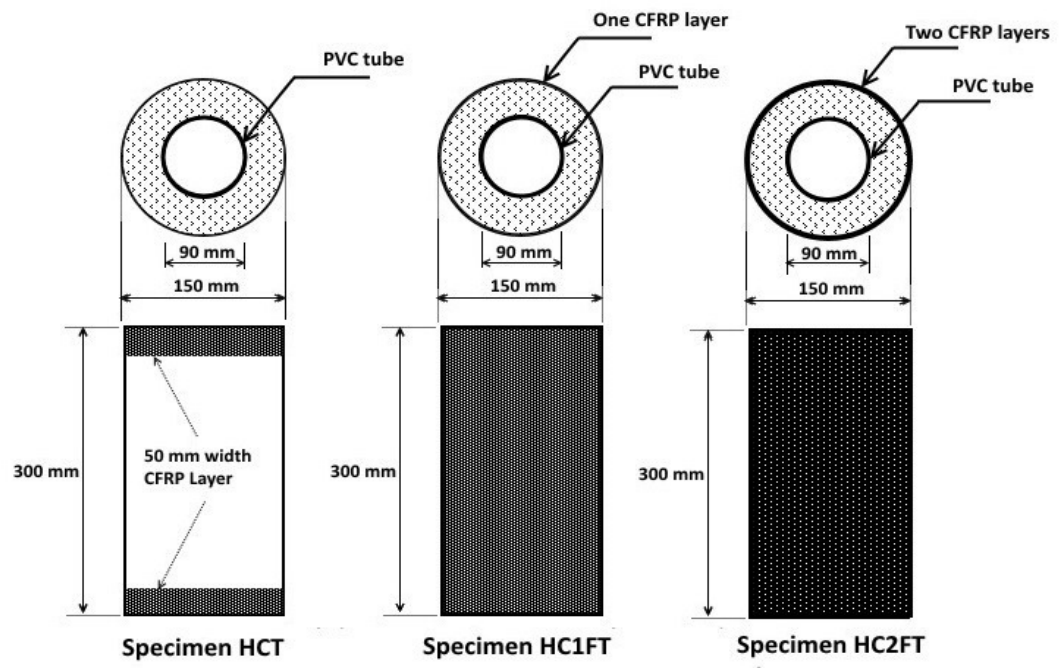

507

(a) Hollow Core Concrete Specimens with inner PVC tube

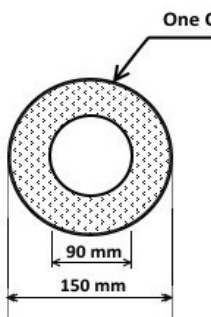

CFRP layer
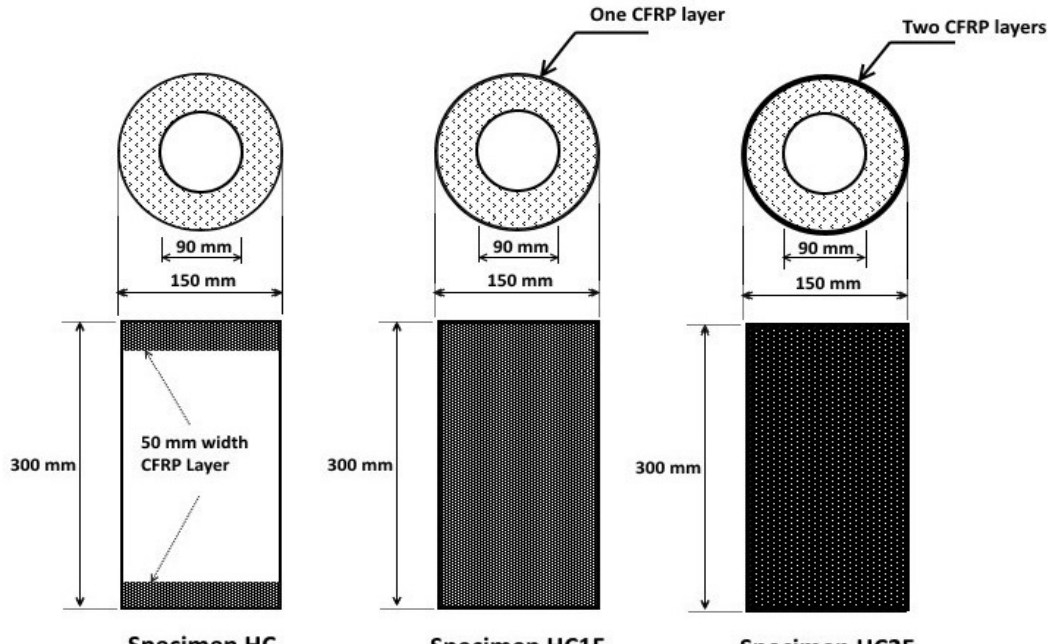

Specimen HC1F

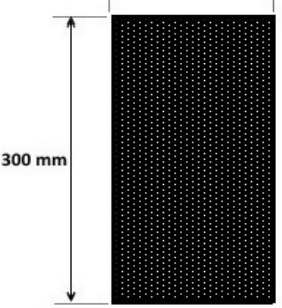

Specimen HC2F

(b) Hollow Core Concrete Specimens
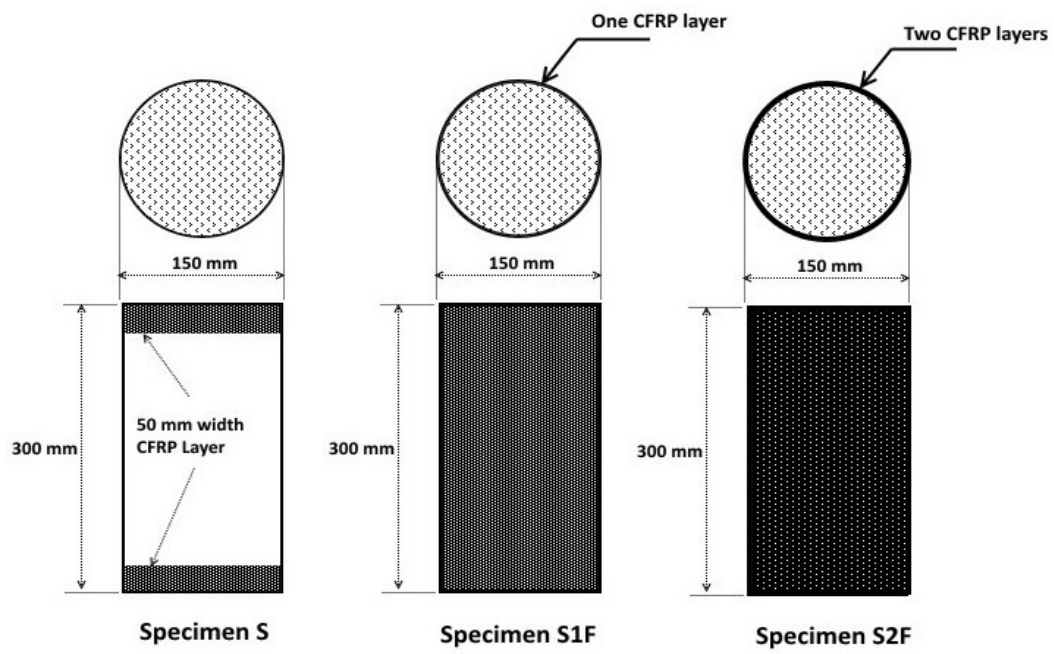

(c) Solid Conrcete Specimens

Figure 1 Details of test specimens 
527

528

529

530

531

532

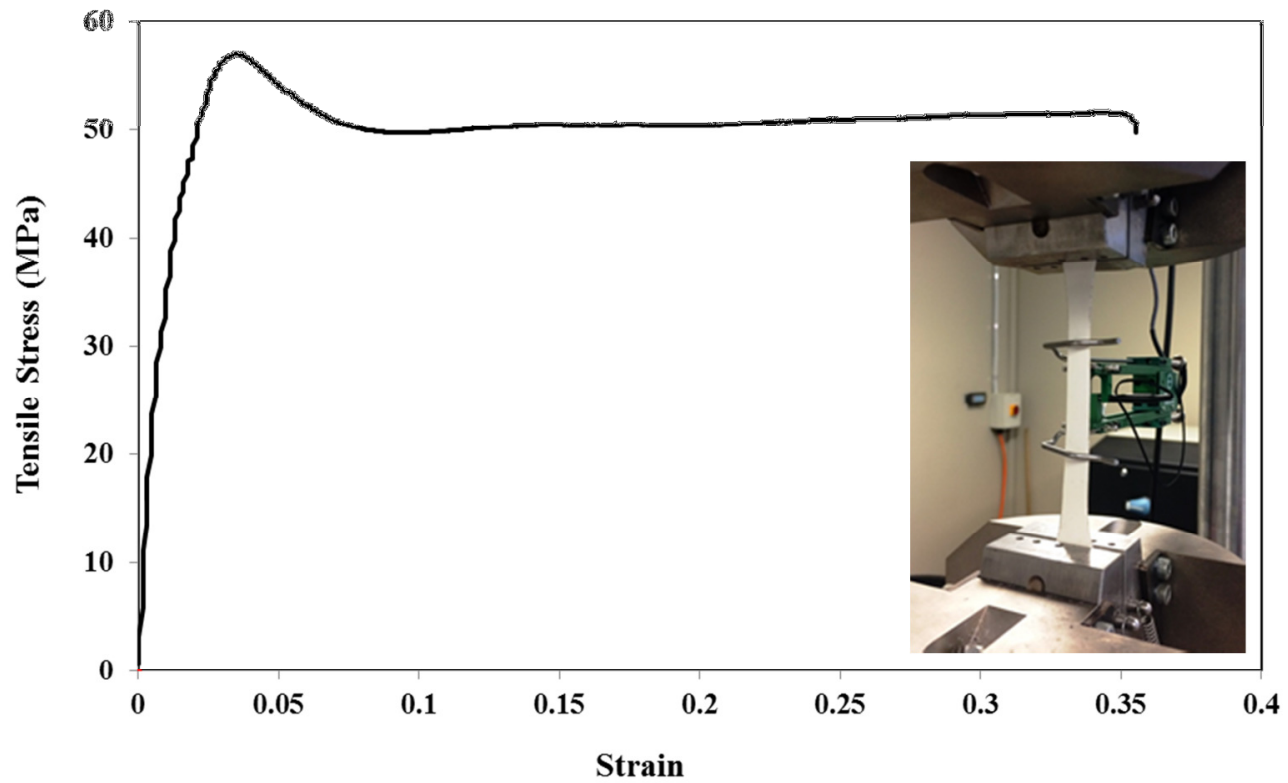

533

Figure 2 Typical tensile stress-strain behaviour of PVC coupon

534

535

536

537

538

539

540

541

542

543

544

545

546 


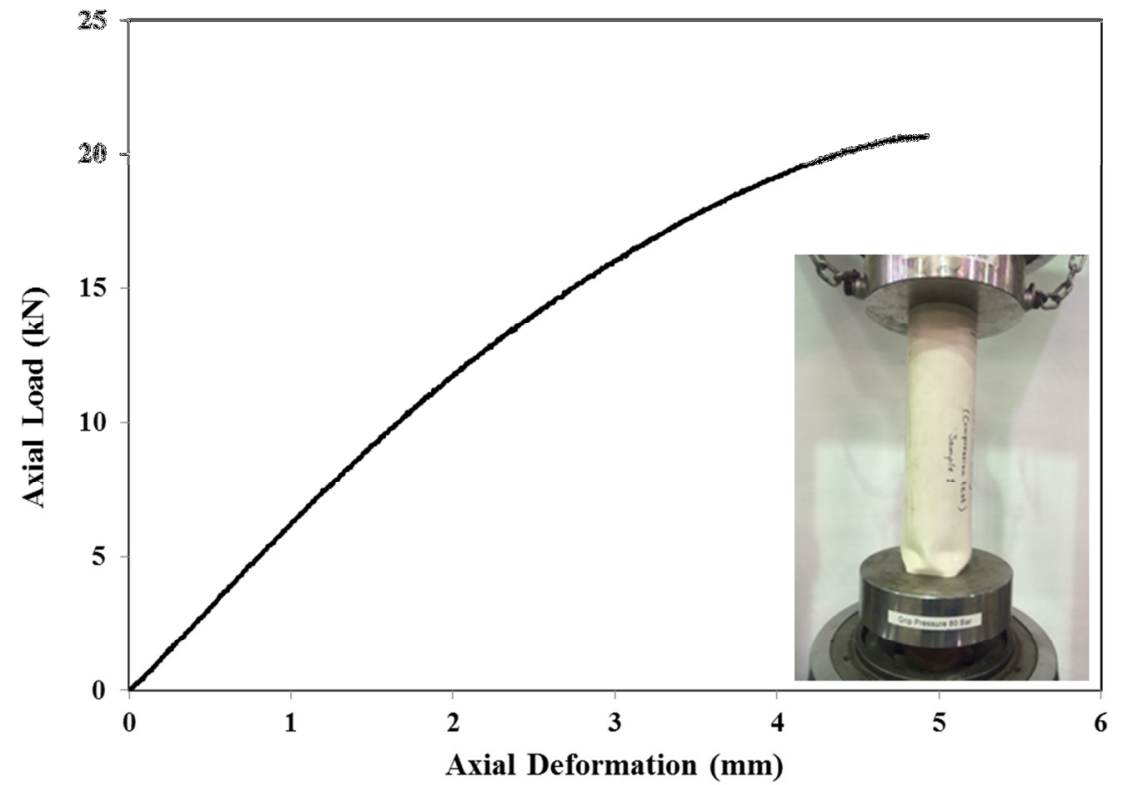

555

Figure 3 Axial compressive load-deformation behaviour of PVC tube

556

557

558

559

560

561 


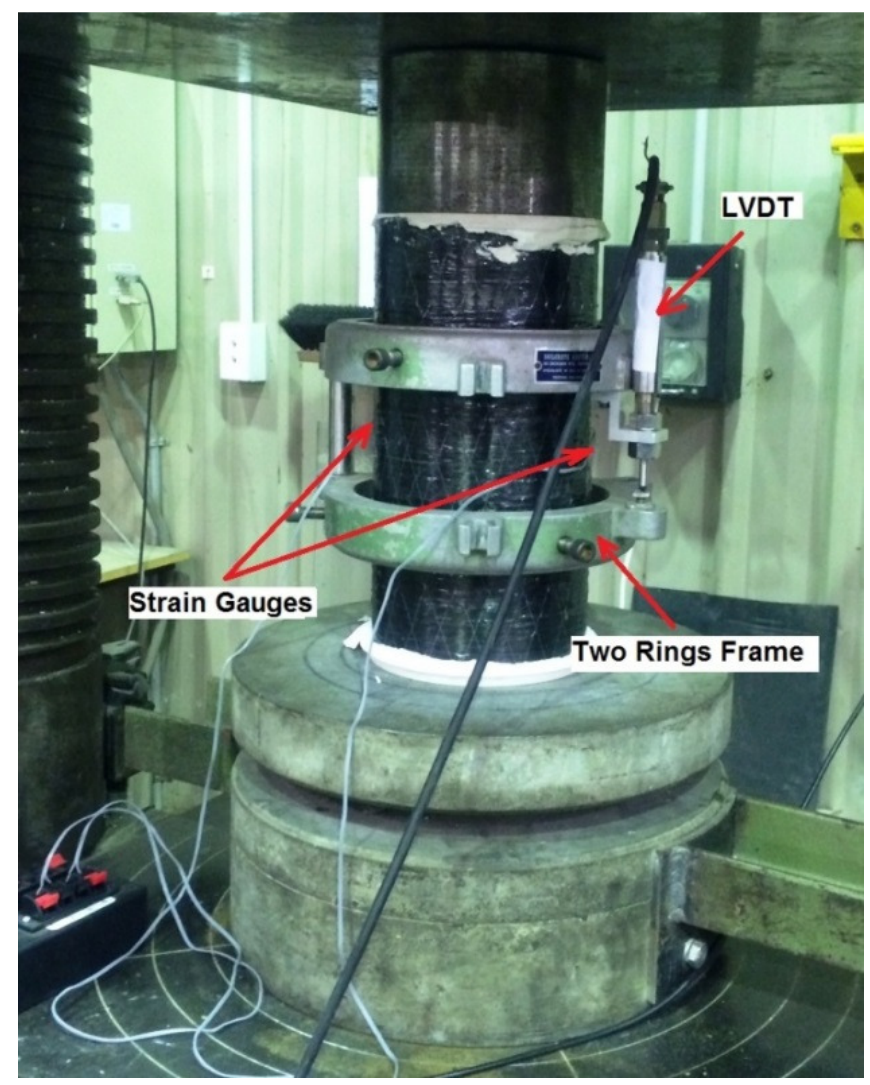

563

Figure 4 Instrumentation of compression test

564

565

566

567

568

569

570

571

572

573

574

575 


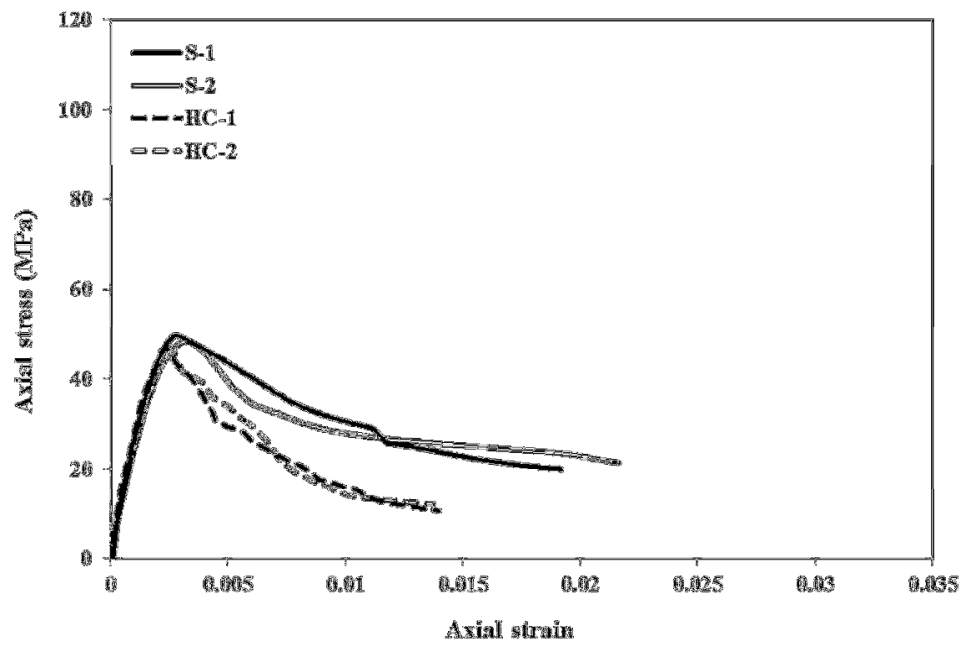

(a) Unconfined solid and hollow specimens

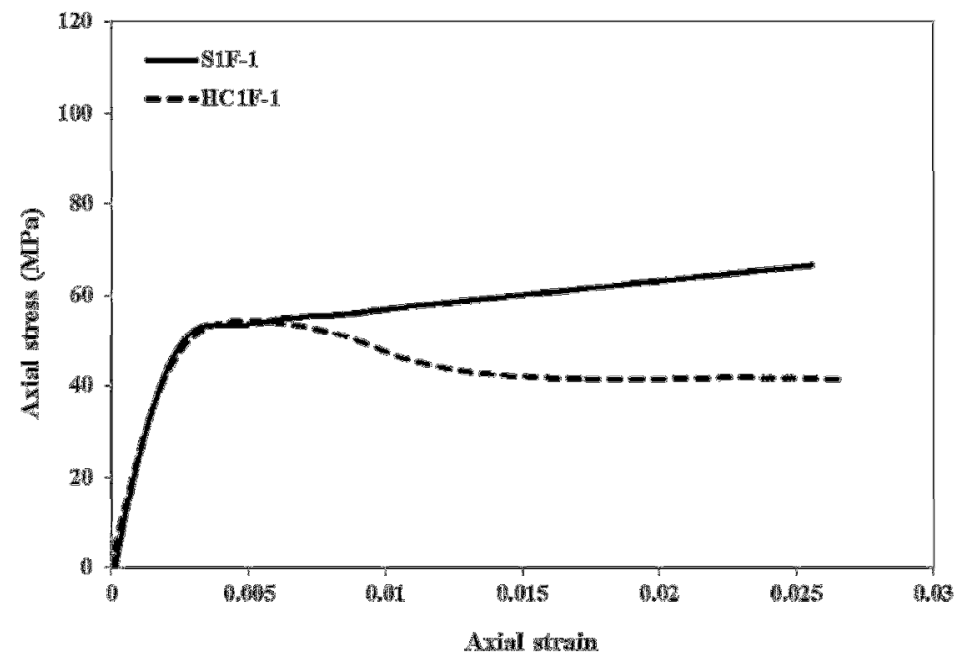

(b) Solid and hollow specimens with one layer of CFRP

590

591

592

593

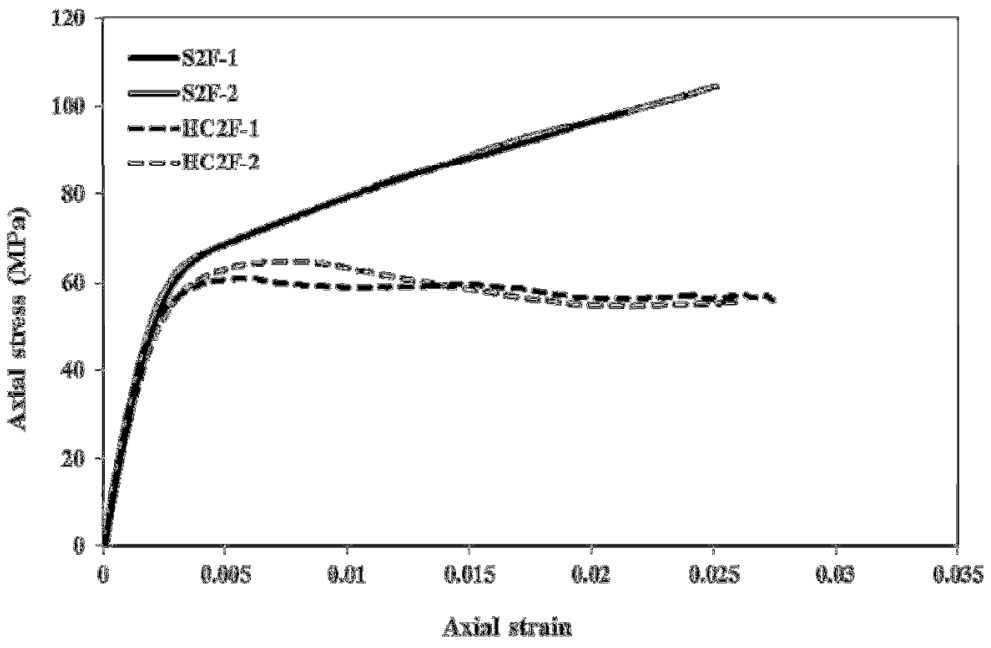

(c) Solid and hollow specimens with two layers of CFRP 


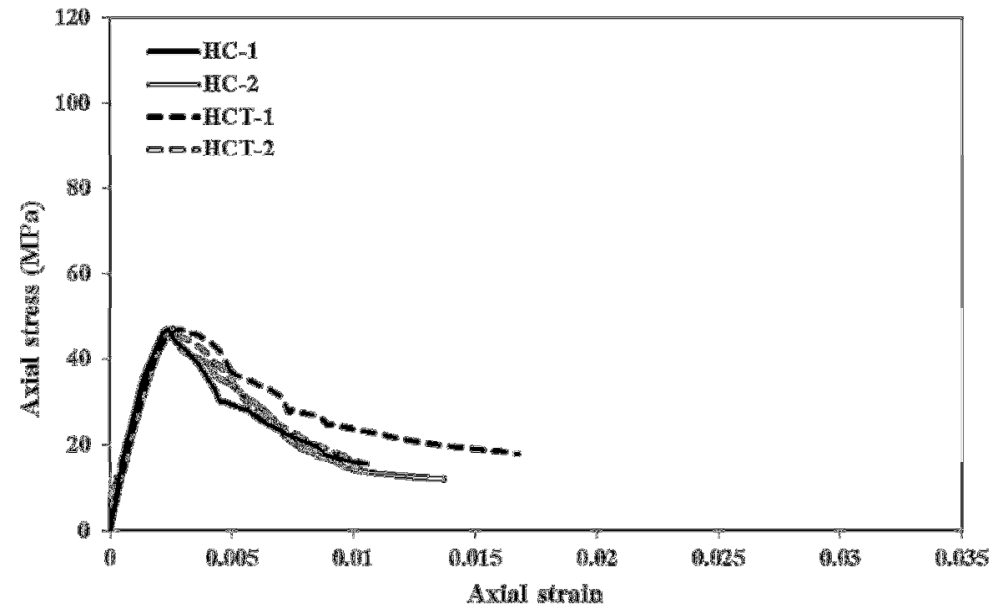

(a) Unconfined Hollow and hollow with inner PVC tube specimens

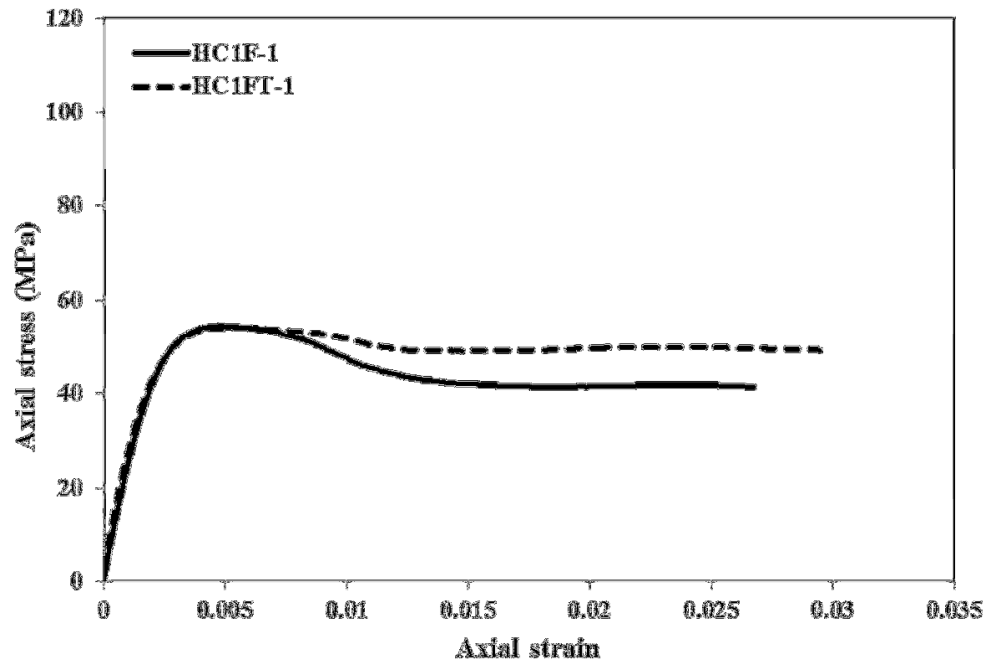

(b) Hollow and hollow with inner PVC tube specimens confined with one layer of CFRP

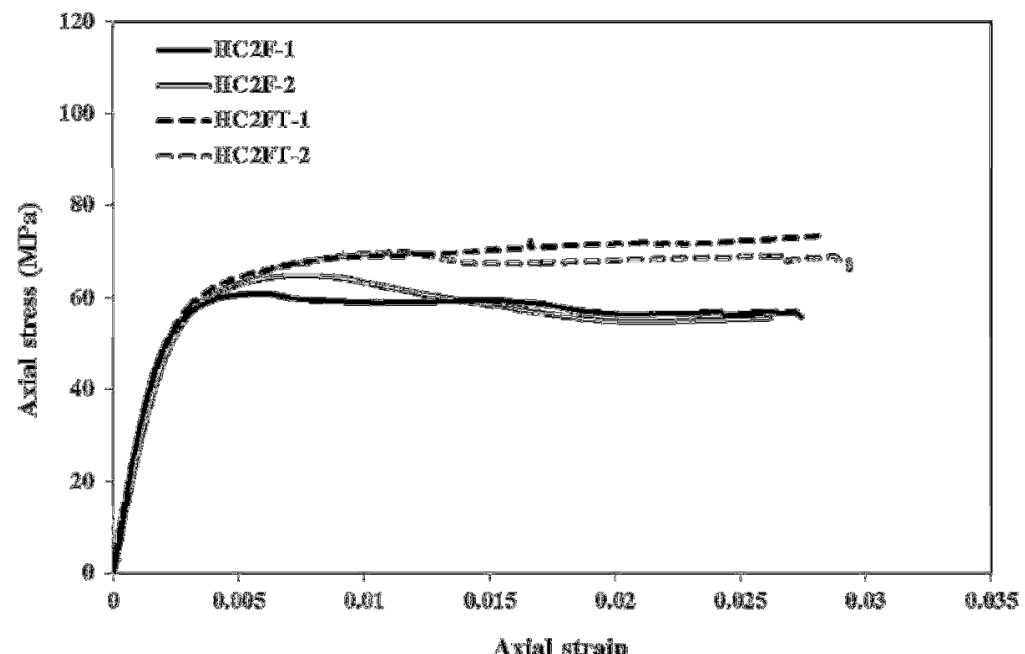

(c) Hollow and hollow with inner PVC tube specimens confined with two layers of CFRP 


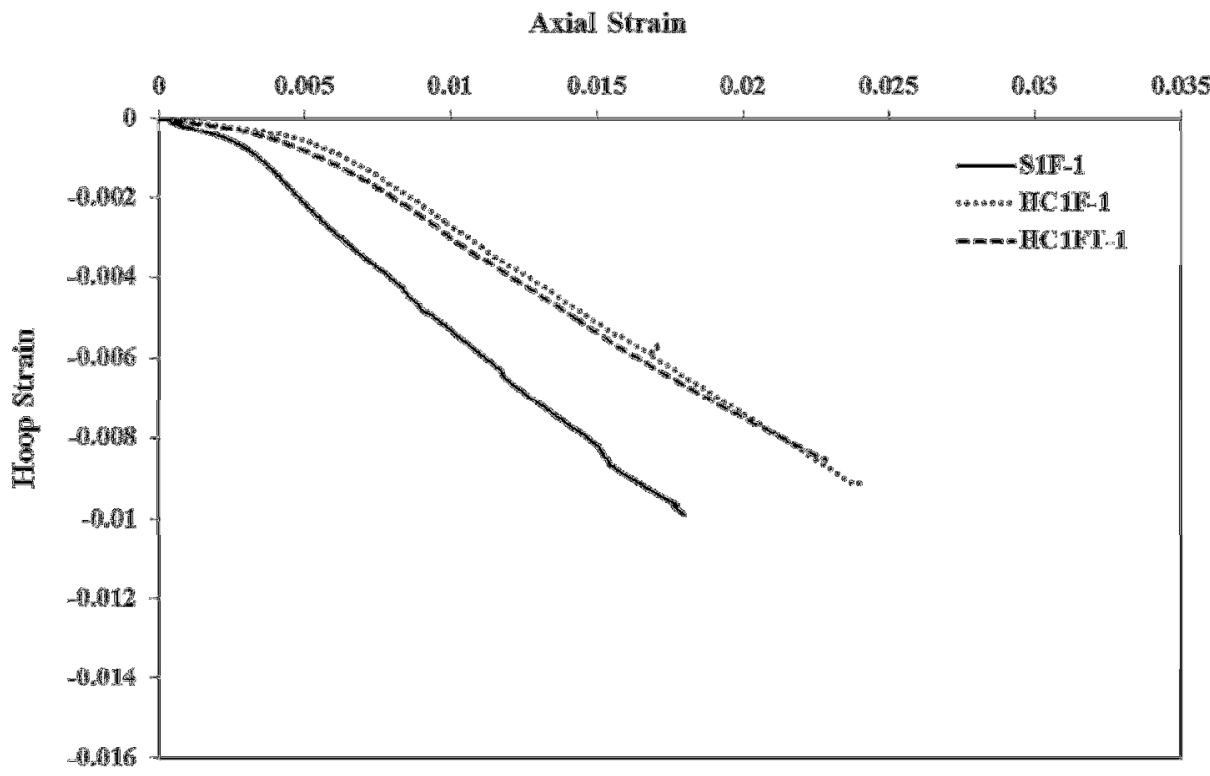

632

Figure 7 Axial-hoop strain response of one layer of CFRP confinement

633

634

635

636

637

638

639

640

641

642

643

644

645

646 
647

648

649

650

651

652

653

654

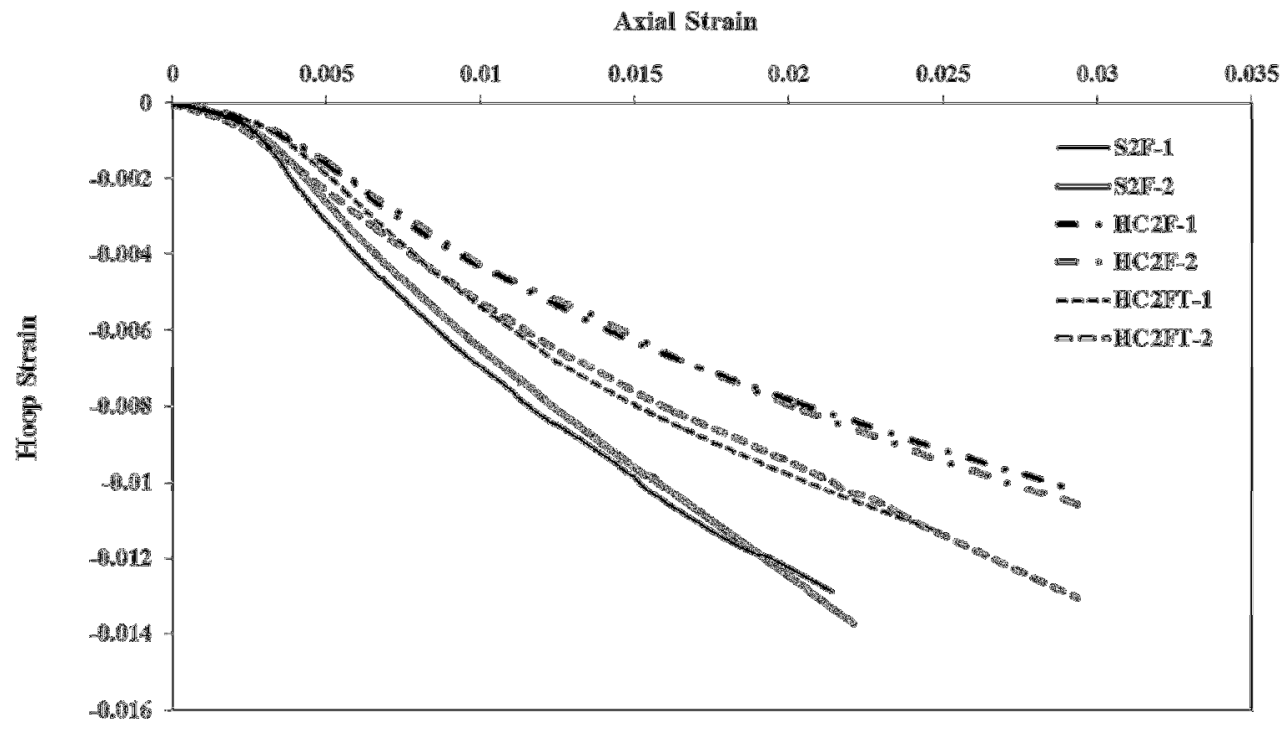

655

Figure 8 Axial-hoop strain responses of two layers of CFRP confinement

656

657

658

659

660

661

662

663

664

665

666

667

668

669 


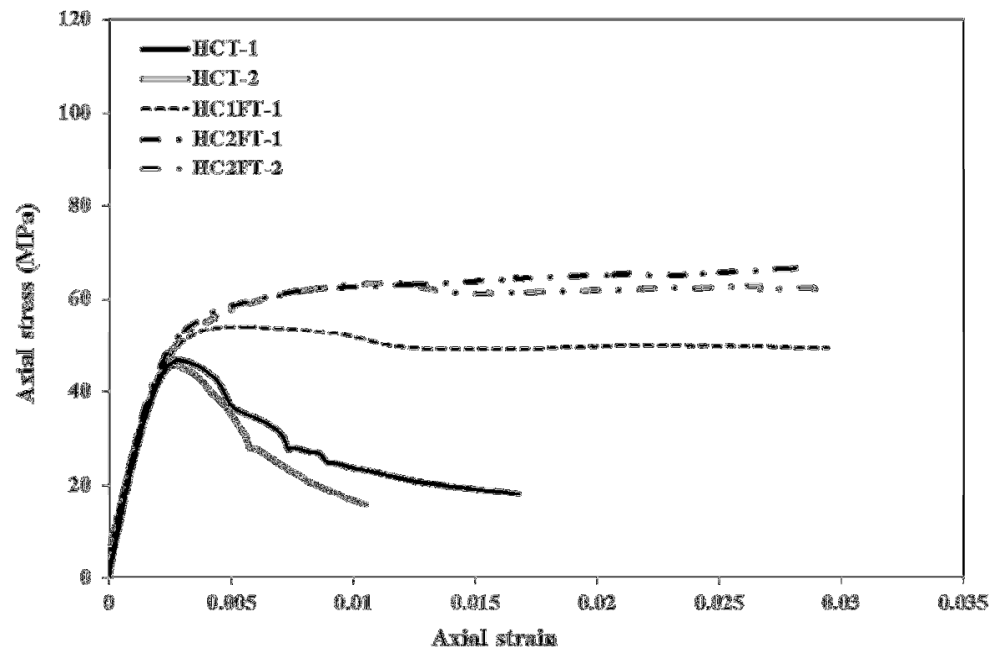

(a) Hollow specimens with PVC tube

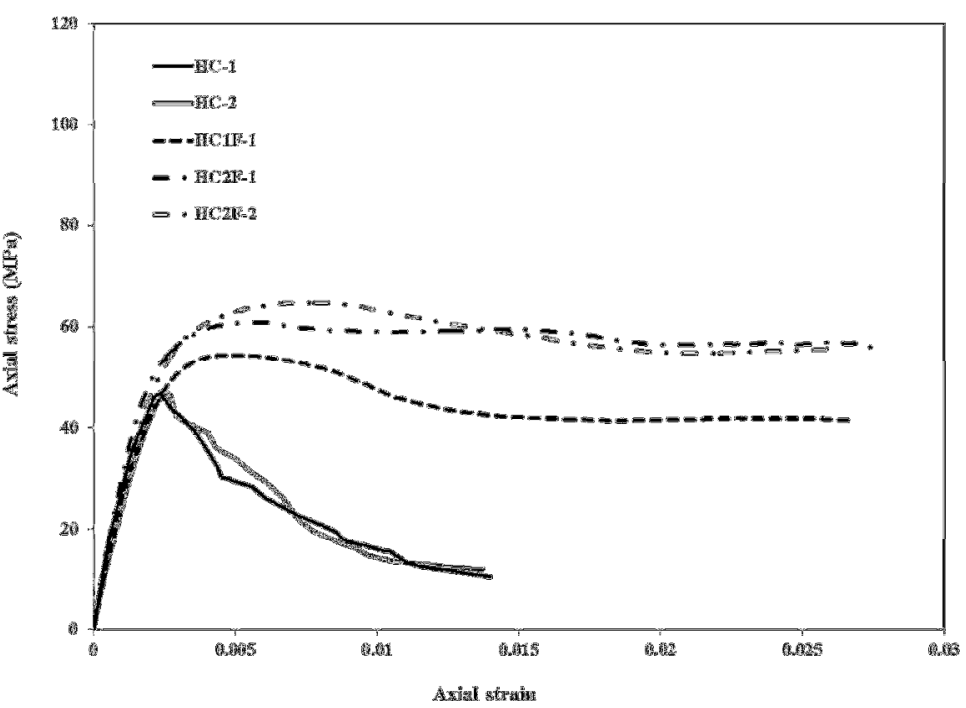

(b) Hollow specimens

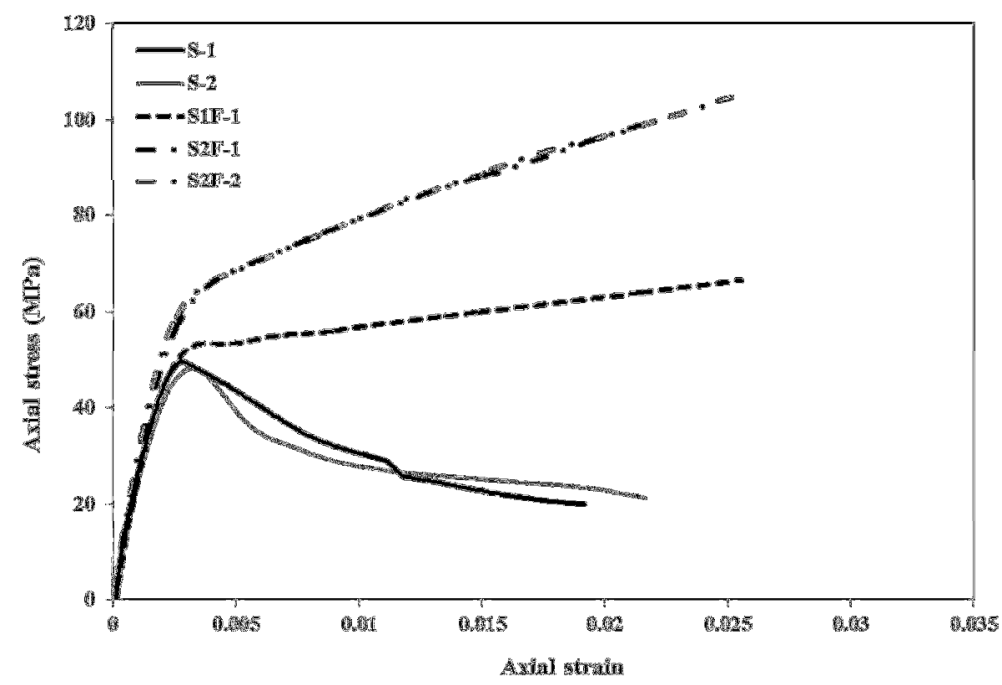

(c) Solid specimens 

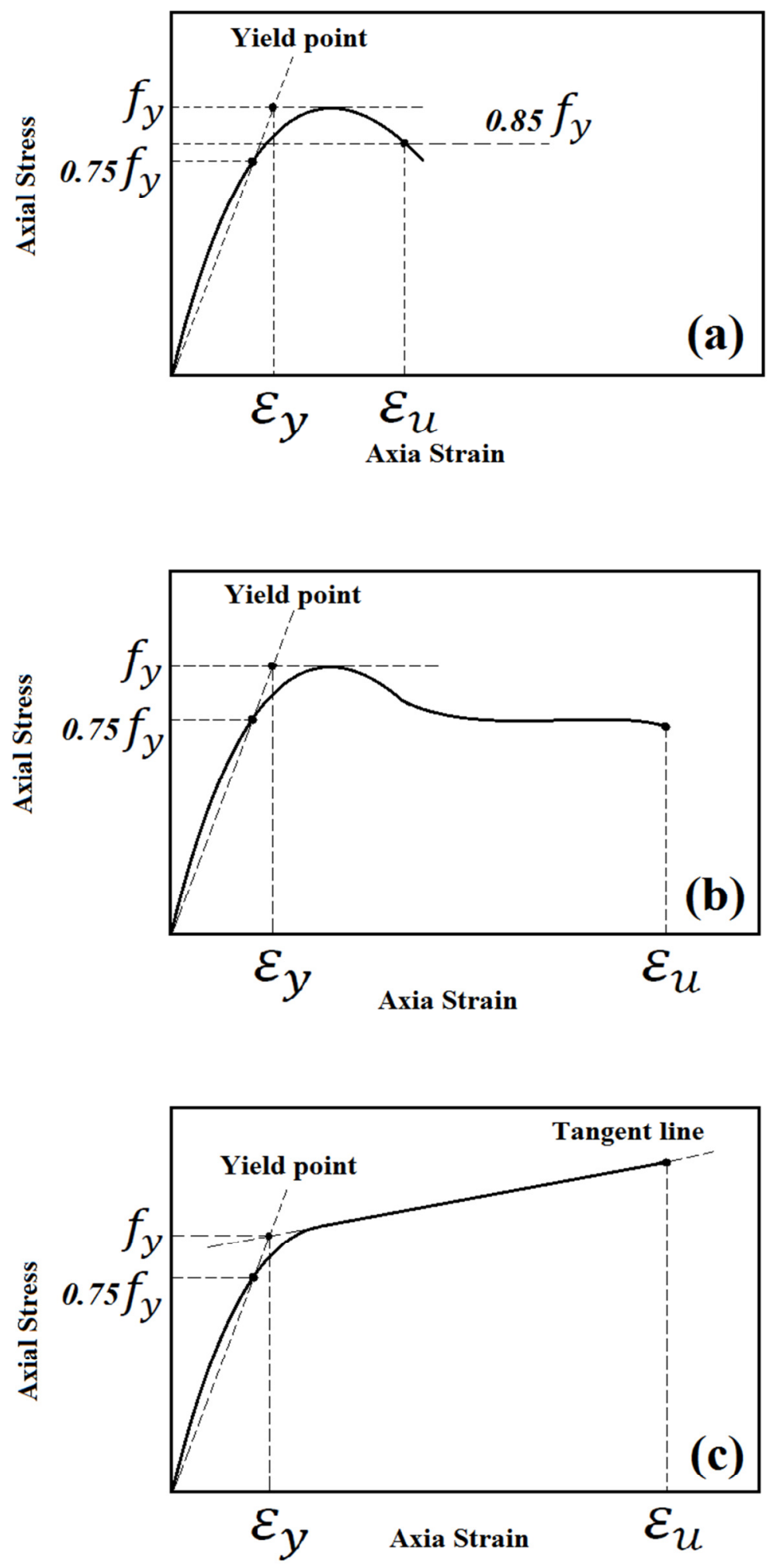

717 Figure 11 Definitions for yield stress and yield strain (a) unconfined specimens; (b) confined specimens with softening behaviour; (c) confined specimens with hardening behaviour (Park, 1989). 


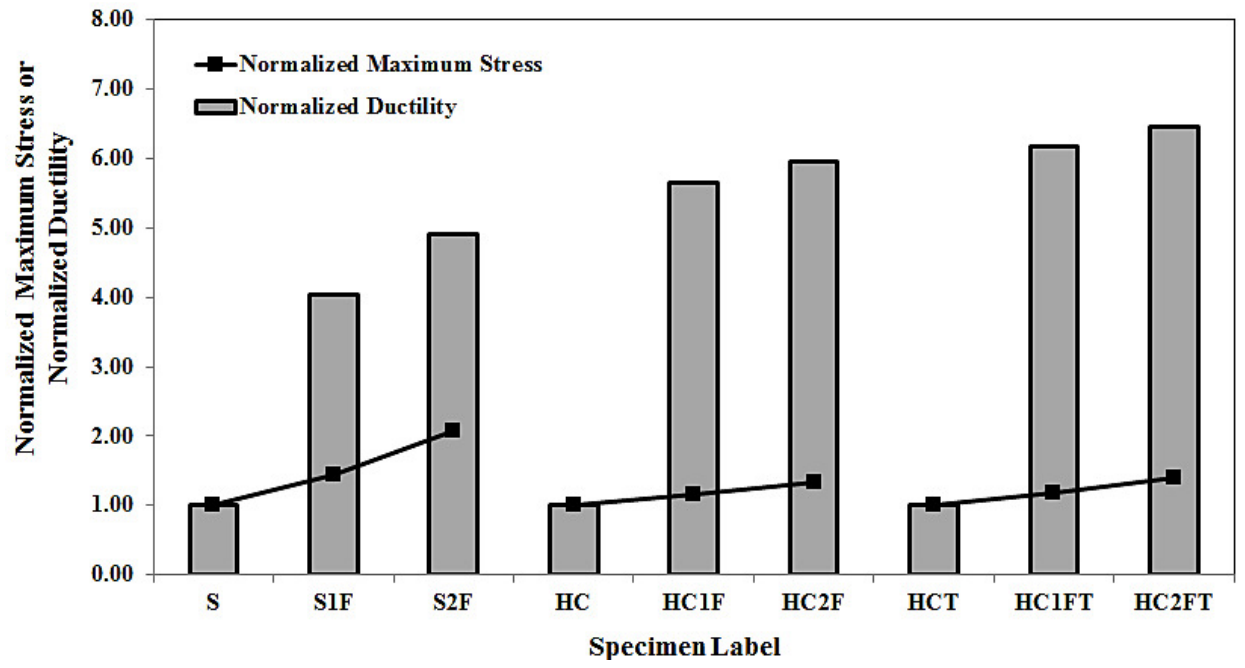

722

Figure 12 Normalized maximum stress and normalized average ductility 